\title{
Father's Support and Mother's Behavior in Stunting Prevention Efforts
}

\author{
Dhani Syahputra Bukit ${ }^{*}$, Alam Bakti Keloko', Taufik Ashar ${ }^{1}$ \\ 1) Fakultas Kesehatan Masyarakat Universitas Sumatera Utara, Medan, Indonesia
}

dhanibukit@usu.ac.id

DOI: http://doi.org/10.29080/jhsp.v5i1.521

Received : Maret 2021, Accepted: Agustus 2021,Published: September 2021

\begin{tabular}{ll}
\hline Keywords & Abstract \\
\cline { 2 - 2 } $\begin{array}{l}\text { Stunting; } \\
\text { Toddler; } \\
\text { Father's support } \\
\text { compared to the usual benchmarks according to the World Health Organization's } \\
\text { Multicentre Growth Reference Study in 2006. The incidence of stunting in infants under } \\
\text { five years of age is a problem that exists in Indonesia and is a major nutritional problem. } \\
\text { Data from the results of monitoring the quality of nutrition in the previous three years } \\
\text { period has the highest prevalence compared to other nutritional problems such as } \\
\text { malnutrition, thinness, and obesity. The purpose of this study was to analyze the } \\
\text { correlation of the father's support and mother's behavior in Stunting Prevention Efforts } \\
\text { in Tuntung 2 Village, Pancur Batu District, Deli Serdang Regency using a cross-sectional } \\
\text { design. This study was done on } 135 \text { mothers who have infants aged } 6-59 \text { months as } \\
\text { respondents. The variables in this study were father's support related to stunting } \\
\text { prevention and the dependent variable in this study is the behavior of the mother in } \\
\text { preventing stunting. The results showed that there was a significant correlation of the } \\
\text { father's support and mothers' behavior in preventing stunting (p <0.038). To increase } \\
\text { efforts of prevent stunting, it is hoped that fathers who have not supported their wives } \\
\text { should be more concerned about their toddler's growth and health. }\end{array}$ \\
\hline
\end{tabular}

\section{Introduction}

Problem health in Indonesia which needs to be directed in the context of preventive and promotive namely Maternal Mortality Rate (MMR) and Infant Mortality Rate (IMR), prevention of stunting, preventing and controlling disease, movement of people, and the layout is like from the practice of health (1). Stunting is the quality of nutrition of infants whose age below than five years than the starting measure that is prevalent in Study Resource Growth Multicentre organization of healthcare world, the numbers z score below -2SD and in grouping is very low when the number of z-score below -3SD (2). Figures adequacy of nutrition is also very influential with the incidence of stunting, according to (3) factors other are associated with the incidence of stunting in under two years is the level of adequacy of protein.

The incidence of stunting (short) in infants whose age below than five years is the issue that there are in Indonesia and become a problem of nutrition the most major. Stunting shall be monitored for a period of time in 1000 days of life with interfering hands open and privileged to the mothers who are pregnant and in infants under two years until the age of 2 years with the service and check the health and quality of nutrition on the activities of Integrated Healthcare Center and class pregnant women (4). Data on the results of monitoring the quality of their nutrition within a period of three years earlier, the short has the prevalence of higher than the issue of nutrient others namely; malnutrition, thinness, and obesity. The prevalence of infants under five years of short rise which in the year 2016 as much as 27.5 percent and in the year 2017 became 29.6 percent. The prevalence of these in Indonesia leaning stagnant. Based basic health research year 2007 showed the prevalence of infants under the age of five years shorter in Indonesia as much as 36.8 percent. In 2010, there was a decrease to 35.6 percent. However, the prevalence of infant's toddler shorter experiencing an increase in the year 2013 is 37.2 percent. The prevalence of infant's toddler is the starting measure of the success of the business program of the government. 
The problem of stunting that occurs in Indonesia is often a recurring problem. The mindset of the community always assumes that mothers are the main foundation in stunting prevention. Whereas the role of mother and father is equal in terms of fulfilling nutrition for children. This equal role of mothers is in accordance with (5), namely the understanding of the community that assumes that nutritional problems focus on only caring for mothers, even though the functions of mothers and fathers are equal in the task of caring for children.

This also makes fathers tend to have a minimal role in nutritional problems in the family. The father only provides material support to the mother so that the father's role in terms of family health and stunting prevention is low. Initial observations made by researchers at the study site also showed the lack of father's support that occurred. Fathers tend to be negligent in terms of the growth of children in the family. In general, fathers only give shopping money to their wives and then leave everything to their wives. The stunting problem that still occurs at the research location is closely related to this condition.

Father's support in preventing stunting is very important and crucial. Fathers who care about their families are more likely to have a lower incidence of stunting compared to fathers who don't care. Fathers who care about health and nutrition will focus more on the development of their children and families. The importance of father's support is in accordance with (6) namely the active role of fathers in parenting by increasing knowledge about stunting, maintaining family nutritional stability and meeting the physiological and psychological needs of mothers and children. The role of the father begins when accompanying the mother's pregnancy until the child is five years old. This role is needed to ensure optimal child growth and development and is free from health problems, one of which is being free from stunting.

Condition of North Sumatra in the year 2016 percentage infants toddler as much as 24.4 percent and occurs increase becomes 28.5 percent year 2017. The 4 areas that have the highest percentage of stunting are Langkat Regency 55.48 percent, Padang Lawas Regency 54.86 percent, North Nias Regency 54.83 percent and Gunung Sitoli City 52.32 percent (7). Based on the data the ministry of health, the District of Deli Serdang Province North Sumatra not include areas in 100 districts / cities highs with the prevalence of stunting, will however not cover the possibility of the occurrence of the found one or more cases of stunting in areas such .

Based on the data analysis results, the father in the Tuntungan 2 village, Pancur Batu Subdistrict are workers who earn income by receiving wages daily by category earning middle to bottom so that in general the mother who takes care of children at home and the involvement of the father is very low in the care of the child. Therefore, it is the underlying research the impetus father will be the behavior of the mother in the effort to prevent stunting in the Tuntungan 2 village.

\section{Methods}

Type of research this is quantitative with the method of cross sectional. The population is mothers who have infants 6-59 months who live in the Tuntungan 2 village of Pancur Batu Subdistrict Deli Serdang regency and samples in research this is the 135 mothers who are determined by random from Hamlet 1 to Hamlet 4 with a method of simple random sampling. The variables were examined in this study is the support of her father as a variable independent and mother's behavioral prevention of stunting as a variable dependent. The data in the study is obtained by the method of interview directly using a questionnaire that contains some questions related to the support of her father and the behavior of the mother in an attempt prevention of stunting and then, the data is analyzed. Analysis of the data is done is bivariate (chi-square).

The variables studied in this study were variables related to father's support related to stunting prevention carried out in fulfilling nutrition and monitoring child growth and development. The instrument that used in this study based on the theoretical aspects related to father's support and the initial survey of the research. Then the dependent variable in this study is the behavior of the mother in preventing stunting. All activities are carried out by the mother in terms of monitoring the growth and development of children and acting directly in increasing the needs of children to avoid stunting problems. The research was conducted directly on research subjects with strict health protocols. The instrument used in this study as a measuring tool for data collection is a questionnaire. The existing questionnaire is the result of refinement of other studies that are in line with this research. Assistance from the village apparatus is very high and facilitates the data collection process. The collected data were analyzed by univariate analysis to see the frequency distribution of each variable and bivariate analysis by chi square statistical test to test the relationship or effect of two variables. Data analysis was carried out using statistical data processing software tools.

\section{Results}

Results of analyses univariate order to know the distribution of the frequency characteristics of a toddler at the location of the research and the distribution of the frequency of the support of her father and 
behavioral prevention of stunting. From the data obtained, carried out the analysis of univariate with results as follows

Table 1. Frequency distribution of characteristics of infants under five (6-59 months) in Tuntungan village, Pancur Batu Subdistrict

\begin{tabular}{lccc}
\hline & Variable & N & \% \\
\hline Toddler Age & & 11.9 \\
$<12$ months & 16 & 10.4 \\
12 months exactly & 14 & 23.0 \\
13 to 24 months & 31 & 25.9 \\
25 to 36 months & 35 & 18.5 \\
37 to 48 months & 25 & 10.4 \\
49 to 60 months & 14 & \\
Gender & & 43.0 \\
Male & 58 & 57.0 \\
Female & 77 & \\
\hline
\end{tabular}

Based on the table above, for the variable age of toddlers data obtained that most of the toddlers aged 25 months to 36 months as many as 35 people (25.9\%). For the gender variable, most of the children under five are female, namely 77 people (57.0\%).

Table 2. Frequency distribution of father support category and mother's stunting prevention behavior

\begin{tabular}{|c|c|c|}
\hline Variable & $\mathbf{n}$ & $\%$ \\
\hline \multicolumn{3}{|l|}{ Father Support } \\
\hline Less Support & 45 & 33.3 \\
\hline Support & 90 & 66.7 \\
\hline \multicolumn{3}{|l|}{ Stunting Prevention Behavior } \\
\hline Behavior Less Good & 61 & 45.2 \\
\hline Good Behavior & 74 & 54.8 \\
\hline
\end{tabular}

Based on the table above, it is known that for the father's support variable, the majority of fathers support their wives in stunting prevention efforts, as many as 90 people $(66.7 \%)$. For the variable of stunting prevention behavior, most of the mothers' behavior was good, as many as 74 people (54.8\%).

The results of bivariate analysis were carried out to determine the relationship between the independent variable and the dependent variable. The results of the bivariate analysis of this study are as follows.

Table 3. Bivariate Analysis of Independent Variables on Dependent Variables

\begin{tabular}{lrrrr} 
& \multicolumn{2}{c}{$\begin{array}{c}\text { Category Stunting Prevention } \\
\text { Behavior }\end{array}$} & P.value & $\begin{array}{c}\text { OR } \\
\text { Variable }\end{array}$ \\
\cline { 2 - 3 } & \multicolumn{2}{c}{$\begin{array}{c}\text { Behavior Less } \\
\text { Good }\end{array}$} & $\begin{array}{c}\text { Good } \\
\text { Behavior }\end{array}$ & \\
\hline Father Support & 26 & 19 & & \\
Less Support & 35 & 55 & 0.038 & 1,486 \\
Support & 61 & 74 & & $(1.037-2.129)$ \\
\hline Total & & & & \\
\hline
\end{tabular}

Based on the above table it is known that the results of analysis of the relationship with the father's support prevention behaviors stunting wear test Chi- Square obtained the numbers $\mathrm{p}=0.038(\mathrm{p}<0.05)$ or can mean there is a correlation support of her father on prevention behaviors stunting.

\section{Discussion}

Stunting is a serious problem, and requires the attention of all parties. According to (8) with reduced Low Birth Weight (LBW), mother's education, household income, and lack of house cleanliness, the threat of stunting in children under five will increase. The prevention of stunting will also be carried out by multi-sectors, according to (9) the stunting prevention approach through multi-sectors to solve nutritional problems for children under 2 years of age. Factors risk of lack of nutrition of children aged under 2 years of both stunting, conditions of heavy weight children under normal and heavy weight low is the weight of the 
body is born low, the condition of the economy, the type of sex, and many members of the household. The need for intervention in order to increase the economic condition of the community and the interference of pregnant women in order to anticipate the birth of babies with low birth weight conditions.

Prevention of stunting could be optimal because most great father to support his wife they are in the prevention of stunting for children under five they like giving permission to go to Integrated Healthcare Center, giving attention to the growth and development of infants and facilitates the mother when it wants to bring a toddler them to Integrated Healthcare Center or officer of health so that the case is of course easier for mothers and add to the spirit of the mother in monitoring the progress of children they each month . Besides that, most big man also actively searching for information related to growth and development of children as asked to worker health related bodies and development of children. Parenting is also an important thing in stunting prevention, according to (10) ways to care for in the family are skills in feeding, caring for, cleaning and getting health services related to stunting cases in infants under the age of five years. Then in line (11) parenting is closely related to the incidence of stunting in children.

According Mustafyani (12) encouragement of the father is every business man is physically, psychological, and social Encouragement element family is very necessary in order to give effect to control the behavior of indivi duals in order to show or not on the behavior of him. Encouragement from fathers for mothers related to stunting for example taking mothers and toddlers to the Integrated Healthcare Center every month, or facilitating mothers and toddlers when they want to go to Integrated Healthcare Center, and supporting mothers in providing exclusive breastfeeding and complementary feeding to toddlers. Factors other in the prevention of stunting is a factor of the economy which should be in optimized by the father. According to (13) factors that become a threat would be a case of stunting in the state that develops with a constant is the condition of the social economy of the family (income families),

The results of this study are in line with research(14) that there is a significant relationship between mothers who receive good family support and exclusive breastfeeding for infants/toddlers $(\mathrm{p}<0.05)$. According to (15) urge the family gives the effect of the good will of behavior to prevent stunting, test results showed there was his influence that positive 0.22 , with the numbers T-Value Statistic 2.57 . The results of the family encouragement parameter coefficient test on the behavior of mothers preventing stunting under five at the Nanga Mau Health Center showed a direct effect of 19.66 percent, an indirect effect of family encouragement on the behavior of mothers to prevent stunting under five with mother's motivation as much as 11.48 percent, meaning the direct effect of support family or father is greater than the indirect influence, namely motivation. Then according to (15) the thing that most dominantly influences the behavior of mothers in preventing stunting in their toddlers is the mother's motivation.

Family is the basis in the prevention of stunting, according (16) the importance of enhancing the role of the family by involving families in meeting the needs of intake of children under five daily so that the incidence of stunting can be reduced. It is also in line with (17) behavior prevention of stunting at the time of the mother pregnant trimester first influenced by the support of the family. Improving maternal nutrition is also another thing in the prevention of stunting. Adequacy of maternal nutrition is an important thing in the problem of stunting; this is in line with (18) that preventing stunting can be carried out by fulfilling the nutrients needed for pregnant women. This is also in line with (19) Social and family support factors have a significant relationship with stunting prevention. An equally important factor in meeting support is education from the father, in line with (19) Father's education is significantly related to the incidence of stunting in toddlers

Other supporting studies are $(20)$ there is a significant correlation $(\mathrm{p}<0.05)$ father's encouragement by giving exclusive breastfeeding to mothers who have babies aged 0 to 6 months at the Sukaraya Pancur Batu Health Center. Furthermore, mothers who get encouragement from a good father have a 12.98 times greater chance of giving exclusive breastfeeding than mothers who get encouragement from a bad father. This is in line with (21) father's support in stunting prevention in the form of physical support and emotional support. According to (22) father's occupation and economic status also play a role in stunting prevention. Then family income is also an important thing in preventing stunting, according to (23) the level of family income with stunting, therefore families must adjust family income to prevent stunting. Other studies that are in line, namely (6) the function of an active father in parenting is carried out by providing increased knowledge about stunting, maintaining nutritional stability of the family and fulfilling the physiological and psychological needs of mothers and children. Father's support in preventing and increasing children's knowledge is also important, this is in accordance with (24) the age of the child, family income, and the involvement of the father in parenting has a significant positive effect on the child's cognitive.

Father's support will also be closely related to the education possessed by all Higher education will make support for stunting prevention more optimal. This is in line with research conducted (25) showing that father's education plays a significant role because educated people are more aware of children's health 
conditions. Low father education can lead to a lack of understanding of children's health and has been found to be associated with nutritional problems in toddlers. Parents who are less educated may have difficulty understanding health information.

The father's active role is also one of the things that can reduce the incidence of stunting. By optimizing the father's role in terms of knowledge, it will have the potential to prevent stunting. This is in line with (6) explaining that the active role of the father in assisting the mother in the pregnancy phase until the child is five years old is very important in terms of optimally monitoring the growth and development of toddlers and can prevent stunting.

The father as one of the breadwinners in the family is also very influential in fulfilling family nutrition which has an impact on stunting prevention. A father who provides routine maintenance to the family will make the child's nutritional condition more fulfilled. This is in accordance with (26) The role of fathers as breadwinners in the family in an effort to improve nutrition has a relationship with the nutritional status of children under five in patrilineal cultural communities in Toineke and Tuafanu villages. Fathers who focus on family and children's growth will make children able to avoid stunting problems. Father's support is very important in preventing stunting problems.

\section{Conclusion}

The conclusion in this study is that there is a relationship between father's support and mother's behavior in preventing stunting. The results of analysis of the relationship with the father's support prevention behaviors stunting wear test Chi- Square obtained the numbers $p=0.038(p<0.05)$ or can mean there is a correlation support of her father on prevention behaviors stunting. Suggestions in this study are to increase stunting prevention efforts, it is hoped that fathers who have not supported their wives to be more concerned and pay attention to the condition of growth and development and health of their children.

\section{Acknowledgements}

Acknowledgments delivered to the Institute for research in tian Sumatera the North and the Faculty of Public Health, University of Sumatera Utara.

\section{Reference}

1. Kemenkes RI. Posyandu dan Puskesmas Sebagai Garda Depan Pengendalian Stunting. Kementerian Kesehatan Republik Indonesia. 2020;

2. Kemenkes RI. Situasi Balita Pendek Di Indonesia. Kementerian Kesehatan Republik Indonesia. 2016;

3. Siringoringo ET, Syauqy A, Panunggal B, Purwanti R, Widyastuti N. Karakteristik Keluarga dan Tingkat Kecukupan Asupan Zat Gizi Sebagai Faktor Resiko Kejadian Stunting Pada Baduta. Journal of Nutrition College. 2020;9(1):54-62.

4. Prastia N, Listyandini R. Perbedaan Kadar Hemoglobin Dan Lingkar Lengan Atas Ibu Hamil Antara Baduta Stunting Dan Normal. Journal of Health Science and Prevention. 2020;4(2):99-104.

5. Negara KS. Pentingnya Peran yang Setara antara Ayah dan Ibu dalam Pemenuhan Gizi Anak. Sekretariat Wakil Presiden. 2021.

6. Iswandari DP, Hariastuti I, Anggriana TM, Wardani SY. Biblio-Journaling sebagai optimalisasi peran Ayah pada 1000 Hari Pertama Kehidupan (1000 HPK. Counsellia: Jurnal Bimbingan Dan Konseling. 2020;10(1):14-27.

7. Direktorat Gizi Masyarakat. Hasil Pemantauan Status Gizi (PSG) Balita Tahun 2017. Direktorat Gizi Masyarakat Jakarta Selatan. 2018;

8. Apriluana G, Fikawati S. Analisis Faktor-Faktor Risiko terhadap Kejadian Stunting pada Balita (0-59 Bulan) di Negara Berkembang dan Asia Tenggara. Media Penelitian Dan Pengembangan Kesehatan. 2018;28(4):247-56.

9. Badriyah LHKK. Ekonomi dan Faktor Lain dengan Stunting, Wasting dan Underweight pada Anak Usia 6-23 bulan di Indonesia. Jurnal Ilmiah Kesehatan. 2019;18(1):26-32.

10. Dwi Bella FAF, N. Hubungan antara Pola Asuh Keluarga dengan Kejadian Balita Stunting pada Keluarga Miskin di Palembang. Jurnal Epidemiologi Kesehatan Komunitas. 2020;5(1):15-22.

11. Masrul. Gambaran Pola Asuh Psikososial Anak Stunting dan Anak Normal di Wilayah Lokus Stunting Kabupaten Pasaman dan Pasaman Barat Sumatera Barat. Jurnal Kesehatan Andalas. 2019;8(1):1126.

12. Dwi Mustafyani AMTHP, Sikap DS. Kontrol Perilaku dan Niat Ibu Dengan Perilaku KADARZI Ibu Balita Gizi Kurang. The Indonesian Journal of Public Health. 2017;12(2):190-201.

13. Budiastutik I, Rahfiludin MZ. Faktor Risiko Stunting pada anak di Negara Berkembang. IAGIKMI \& Universitas Airlangga. 2019;3(3):122-9.

14. Rubinem. Faktor-Faktor yang Berhubungan dengan Perilaku Pemberian ASI Eksklusif di Puskesmas Srondol Kota Semarang Tahun 2012. Skripsi Jakarta:Universitas Indonesia. 2012; 
15. Wulandari HW, Kusumastuti IPPB, Kader P. Dukungan Keluarga dan Motivasi Ibu terhadap Perilaku Ibu dalam Pencegahan Stunting pada Balitanya. Jurnal Ilmiah Kesehatan. 2020;19(2):73-80.

16. Rahmawati U, Aini latifa, Rasni HHPPK dengan KS pada B di KA. Jember. E-Journal Pustaka Kesehatan. 2019;7(2):112-9.

17. Salamung N, Haryanto J, Sustini F. Faktor-Faktor yang Berhubungan dengan Perilaku Pencegahan Stunting pada Saat Ibu Hamil di Wilayah Kerja Puskesmas Kabupaten Bondowoso. Jurnal Penelitian Kesehatan "SUARA FORIKES" (Journal of Health Research “Forikes Voice.” 2019;10(4):264-9.

18. Sutarto MD, Stunting IR. Faktor Resiko dan Pencegahannya. Jurnal Kesehatan dan Agromedicine. 2018;5(1):540-5.

19. Cahyani VU, Yunitasari E, Indarwati R. Transcultural Nursing (Social Support as the Main Factor in Providing Specific Nutrition Interventions for Children Aged 6-24 Months with Stunting Events based on Transcultural Nursing. Pediomaternal Nursing Journal. 2019;5(1):77-88.

20. Ivana Feby. Hubungan karakteristik Ibu dan Dukungan Sosial terhadap Pemberian ASI Eksklusif pada Ibu Menyusui di Wilayah Kerja Puskesmas Sukaraya Pancur Batu Tahun 2018. Politeknik Kesehatan Medan. Politeknik Kesehatan Kemenkes RI Medan; 2018.

21. Krisnana I, Suryawan A, Muftiyaturrohmah M. Analysis of Fathers' Support Based on Maternal Perceptions Through Stunting Incidence in Toddler at Coastal Areas. Systematic Reviews in Pharmacy. 2020;11(5):761-7.

22. Ariati. P Risk Factors Causes Of Stunting In Toddlers Aged 23-59 Months Oksitosin, Kebidanan. 2019;6(1):28-37.

23. Setiawan E, Machmud R. Faktor-Faktor yang Berhubungan dengan Kejadian Stunting pada Anak Usia 24-59 Bulan di Wilayah Kerja Puskesmas Andalas Kecamatan Padang Timur Kota Padang Tahun 2018. Jurnal Kesehatan Andalas [Internet]. 2018;7(2). Tersedia pada: http://jurnal.fk.unand.ac.id

24. Aritonang SD, Hastuti D, Puspitawati HM. Father Involvement in Parenting, and Cognitive Development of Children Aged 2-3 Years in the Stunting Prevalence Area. Jurnal Ilmu Keluarga Dan Konsumen. 2020;13(1):38-48.

25. Zogara AU, Pantaleon MG. Faktor-faktor yang Berhubungan dengan Kejadian Stunting pada Balita. Jurnal Ilmu Kesehatan Masyarakat. 2020;9(2):85-92.

26. Herwanti E Hubungan Peran Ayah Dalam Upaya Perbaikan Gizi Dengan Status Gizi Balita Pada Masyarakat Budaya Patrilineal Di Desa Toineke Dan Tuafanu Puskesmas Kualin Kabupaten Timor Tengah Selatan. Poltekkes Kemenkes Kupang; 2016. 